\title{
:28:嘴文
}

\section{Production of Zirconia Microspheres Using a Newly Developed Semi-Continuous System of Agglomeration in Liquid*}

\author{
by Winston GUINTO ${ }^{1}$, Tsuyoshi HIRAJIMA ${ }^{2}$, Masami TSUNEKAWA ${ }^{3}$ \\ Yoshihiro NISHISU ${ }^{4}$ and Masayoshi NAKAMURA ${ }^{5}$
}

\begin{abstract}
The production of zirconia microspheres in a newly developed semi-continuous system of agglomeration in liquid was investigated. Semi-continuous agglomeration experiments were carried out using zirconia powder containing 2.6 mol\% of $\mathrm{Y}_{2} \mathrm{O}_{3}$ (surface area $=6.76 \mathrm{~m}^{2} / \mathrm{g}$, mean particle diameter $=0.45 \mu \mathrm{m}$ ), a paraffin type organic liquid as suspending media and four levels of bridging liquid additions, i.e. $0.095,0.105,0.115$ and $0.125 \mathrm{ml} / \mathrm{g}$. Several runs were performed for each bridging liquid dosage. A decrease in the amount of bridging liquid prolongs agglomeration time and decreases the diameter of agglomerates. The sintered agglomerates produced by using different dosages of bridging liquid have sphericity, i.e. the ratio of the maximum length and breath diameter, $<1.14$, density $>5.93 \mathrm{~g} / \mathrm{cm}^{3}$, mean diameter of $282 \sim 701 \mu \mathrm{m}$ and narrow size distribution. The agglomeration time and properties of agglomerates obtained from several runs of the semi-continuous agglomerator exhibited good reproducibility. However, the semi-continuous agglomerator can be sensitive to even minor changes in bridging liquid dosage which affect the agglomeration time and the properties of agglomerates. Consequently, there is a great need to develop a reliable instrumentation method for on-line monitoring of the agglomeration process. Cognizant to this need, the possibility of using power consumption, temperature, pressure, laser attenuation and noise relative energy for on-line monitoring was investigated. It was concluded that on-line monitoring of the agglomerate growth during the process of agglomeration in liquid was possible by measuring the laser attenuation and noise relative energy.
\end{abstract}

KEY WORDS: Zirconia Micro-Spheres, Agglomeration in Liquid, Semi-Continuous Agglomerator, On-line Monitoring

\section{Introduction}

High performance micro-spheres offer a number of industrial applications. Mixing, dispersing and ultrafine grinding of fine ceramics, super conducting materials, minerals, coal, etc. are some applications that necessitate the use of microballs. The authors reported the design and successful testing of a batchwise three liter agglomerator for the production of zirconia microspherical agglomerates by the methods of agglomeration in liquid ${ }^{1)}$. Batch operation is suitable for producing good spherical shape agglomerates with uniform size distribution ${ }^{2)}$. However, batch operations are labor intensive and time consuming. In a batch process, the agglomeration vessel is disassembled after each run and cleaned to insure uniform quality of the product. Cleaning the agglomerator is tedious and laborious. Considerable time is also wasted for assembling and disassembling. The process of

\footnotetext{
* Received June 3, 1992: accepted for publication September 11, 1992

$1 \sim 3$. Faculty of Engineering Hokkaido University, Kita-ku, Sapporo, 060, Japan

1. Graduate Student

2. Instructor, Dr.

3. Associate Professor, Dr.

4. Graduate Student (Present: National Institute for Resources and Environment)

5. Showa Shell Sekiyu, K. K.
}

agglomeration in liquid is readily adaptable to continuous operation. To date several continuous systems have been developed mostly for the upgrading of $\mathrm{coal}^{3)}$, recovery of soots ${ }^{4) 5)}$, etc. However these systems are not normally used when there is a severe restriction with regards to the properties of the product. A semi-continuous system is a compromise between the batch and continuous system. It shortens the cycle time of production and is more cost effective than a batch process. In the industrial point of view, a semi-continuous process that does not necessitate the disassembly of agglomerator is advantageous. In this paper, the production of zirconia microspheres in a newly developed semi-continuous agglomeration system was investigated.

The bridging liquid dosage greatly affects the results of agglomeration process. Slight variations in process parameters can greatly affect the properties of final agglomerates. It is imperative to develop an on-line monitoring system in order to repeatedly produce agglomerates with desirable properties in terms of size, density and sphericity. A reliable monitoring system also offers the possibility of full automatic operation of the agglomeration system. For the development of an effective monitoring system, power, temperature, pressure, laser attenuation and noise emission are measured during the process of agglomeration in liquid. Monitoring methods utilizing changes in agitation power and temperature have 
been reported by other workers ${ }^{6) 7)}$. In the process of agglomeration in liquid, it is generally observed that complete agglomeration is accompanied by the clearing of slurry. It is considered that an electronic eye, consisting of a laser beam and a photodiode, can replace the human eye in detecting the time of complete agglomeration. It is also postulated that distinct noises are emitted during the process of agglomeration in liquid. It is considered that measuring the noises emitted during the process of agglomeration may yield relevant information that can be correlated to the properties of agglomerates.

\section{Experimental}

\subsection{Materials}

The starting material used was a commercially available zirconia stabilized with 2.6 mole\% of $\mathrm{Y}_{2} \mathrm{O}_{3}$. A typical lot analysis (weight percent) of this material was $4.58 \mathrm{Y}_{2} \mathrm{O}_{3}, 0.02$ $\mathrm{CaO}, 0.03 \mathrm{Na}_{2} \mathrm{O}$, balance $\mathrm{ZrO}_{2}$. The equilibrium moisture content of this material was approximately $0.3 \%$. The specific surface area was $6.76 \mathrm{~m}^{2} / \mathrm{g}$ and the average particle size was $0.45 \mu \mathrm{m}$. The size distribution of this powder fits the RosinRammler distribution with absolute size constant $d_{0}=0.635$ $\mu \mathrm{m}$ and distribution constant $\eta=1.075$. The suspending liquid used was an aliphatic hydrocarbon containing isoparaffin. Some important properties of this organic liquid are; density: $0.75 \mathrm{~g} / \mathrm{cm}^{3}$, interfacial tension: $43.01 \mathrm{dyn} / \mathrm{cm}$, and carbon number: 7 to 12 . The bridging liquid used was demineralized distilled water.

\subsection{Method of Agglomeration}

Zirconia powder weighing 100 grams was suspended in $3,200 \mathrm{~cm}^{3}$ of the paraffin type organic liquid. The suspension was fed into the agglomeration vessel, shown in Fig. 1, through the feed spout and conditioned at 1,840 rpm for $10 \mathrm{sec}$. In another paper ${ }^{1)}$, it was shown that $1,840 \mathrm{rpm}$ is the impeller speed necessary to reduce the agglomerate porosity to one that will yield high density after sintering. Desired a-
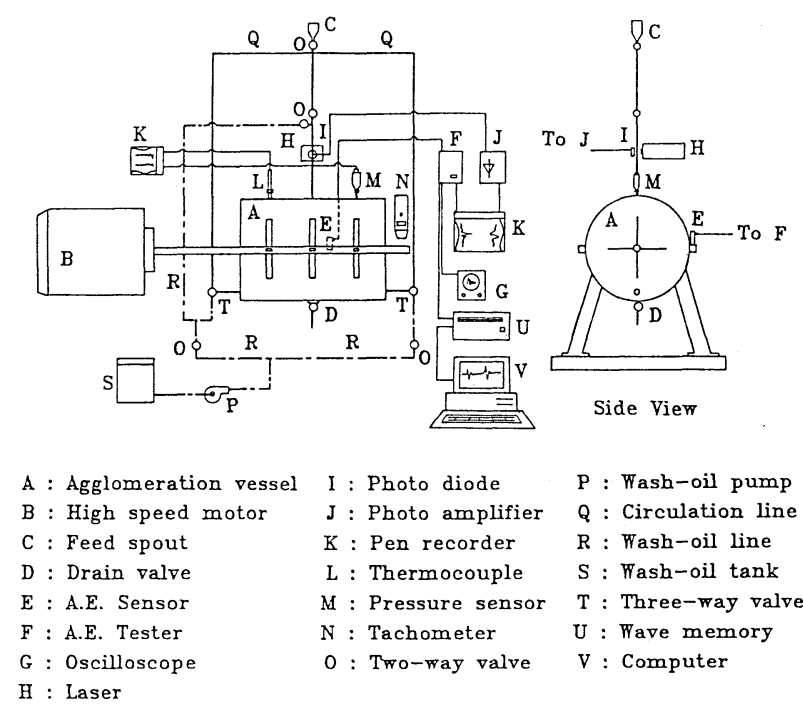

$$
\begin{array}{ll}
\text { I : Photo diode } & \text { P : Wash-oil pump } \\
\text { J : Photo amplifier } & \text { Q : Circulation line } \\
\text { K : Pen recorder } & \text { R : Wash-oil line } \\
\text { L : Thermocouple } & \text { S : Wash-oil tank } \\
\text { M : Pressure sensor } & \text { T : Three-way valve } \\
\text { N : Tachometer } & \text { U : Wave memory } \\
\text { O : Two-way valve } & \text { V : Computer }
\end{array}
$$

Fig. 1 Semi-continuous agglomeration system with monitoring devices. mounts of bridging liquid, i.e., demineralized distilled water, was added through a microvalve fitted at the side of the agglomerator and the impeller was revved to $1,840 \mathrm{rpm}$. Agitation was stopped $5 \mathrm{~min}$ after complete agglomeration was attained. Complete agglomeration is defined as the stage when all the feed powder formed into discrete agglomerate and manifested by the least turbidity of suspension. The $5 \mathrm{~min}$ is a "shape-up time" arbitrarily chosen to establish a basis of comparison for the agglomeration results. The agglomerates were recovered and the agglomerator was cleaned using the washing system described in the next section.

After agglomeration, the products were dried at $60^{\circ} \mathrm{C}$ for a day and sintered at $1,450^{\circ} \mathrm{C}$. The firing schedule consists of heating to the sintering temperature at a rate of $150^{\circ} \mathrm{C} / \mathrm{h}$, holding for 2 hours, cooling to $400^{\circ} \mathrm{C}$ at a rate of $200^{\circ} \mathrm{C} / \mathrm{h}$ and natural cooling to room temperature. The density of sintered product was measured by using the Archimedes principle, i.e. the pycnometer method. The diameter, size distribution, sphericity and surface smoothness of the agglomerates were determined by using an image analyzer, Luzex II by Nireco Corp., equipped with a microscope. Sphericity is defined as $M L / B D$ where $M L$ is the maximum length and $B D$ the breadth diameter.

Recovery refers to the ratio of the weight of green agglomerates recovered at the 150 mesh sieve to that of the feed powder. The amount of bridging liquid added or dosage is defined as the ratio of the volume of bridging liquid to the weight of feed powder, i.e. $\mathrm{ml} / \mathrm{g}$. Relative density refers to the percentage of the density of sintered agglomerates or compact measured by the Archimedes principle against the theoretical density of zirconia assumed as $6.1 \mathrm{~g} / \mathrm{cm}^{3}$.

\subsection{Equipment}

2.3.1 Agglomeration system The equipment used for semi-continuous agglomeration is illustrated in Fig. 1. The originally batchwise agglomerator was modified and retrofitted with a washing system to facilitate recovery of agglomerates and cleaning of the agglomerator without disassembling. During agglomeration, the rotating impellers push the suspension to circulate through the transparent vinyl circulation tubes. The slurry exits at the top of the agglomeration vessel through a tube with an internal diameter of $18 \mathrm{~mm}$. The flow splits into two at a T-joint $50 \mathrm{~cm}$ from the top of the vessel and re-enters the agglomeration vessel at both sides. The internal diameter of the tubes connected to the $\mathrm{T}$-joint was $9 \mathrm{~mm}$.

During agglomeration, the electrical power consumed by the motor was measured by a digital power tester, Hi-Tester 3184 Hioki Corp. The temperature and internal pressure were measured by a thermocouple and pressure sensor attached at the upper half of the agglomeration vessel.

After agglomeration, organic liquid was pumped into the vessel at a rate of $42 \mathrm{l} / \mathrm{min}$. The organic liquid enters the vessel through the side and top openings. The agglomerates were pushed out by the incoming organic liquid and recovered at the drain by using a 150 mesh sieve. In the initial stage of washing, first $10 \mathrm{~min}$, the impeller was not rotated to avoid 
breaking the agglomerates. After most of the agglomerates were ejected, the impeller was rotated for $5 \mathrm{~min}$ to expel the unagglomerated materials and flocs inside the vessel and circulation tubes. New or filtered organic liquid was placed in the tank and the washing procedure was repeated.

2.3.2 Optical system The circulation tubes are made of transparent vinyl tube which serve as windows where the progress of agglomeration can be observed. The "electronic eye" consists of a $0.5 \mathrm{~mW}$ He-Ne laser (NEC Corp.; $\lambda=$ $632.8 \mathrm{~nm}$ ) and a photodiode. The laser was used to irradiate the slurry that passes through the transparent circulation tube just above the agglomerator. The transmitted light is detected by a photodiode mounted at the opposite side of the tube. The photodiode have a linear relation between the light intensity and electrical current. This signal is amplified and recorded in volts in a personal computer through an $\mathrm{A} / \mathrm{D}$ converter.

2.3.3 Noise monitoring system Noise emissions were detected by a sensor fixed at the side of the vessel. The sensor was a wide band piezoelectric transducer with a $\pm 10 \mathrm{~dB}$ response over the frequency range $100 \mathrm{kHz}$ to $2 \mathrm{MHz}$. A high temperature $\left(270^{\circ} \mathrm{C}\right)$ silicon-rubber glue was used to attach the sensor to the vessel's external wall. The noise signals detected by the sensor were processed in a portable type AE Tester, Model 9501 NF Corp.

In the tester the signal was passed through a $100 \mathrm{kHz}$ high pass filter. After filtering, the signal was processed through an attenuator and an amplifier to adjust the level of the signal in accordance with the sensitivity or gain setting. In these experiments, the gain was $56.5 \mathrm{~dB}$. At this point, the adjusted signal called RF was monitored using an oscilloscope. The RF signal was further processed in a half-wave rectifier to obtain a dc output. The rise and fall time constants of this processor are $1 \mathrm{~ms}$ and $1.5 \mathrm{~ms}$, respectively. This dc output is considered to indicate the impact energy of particles and will be referred to as relative energy or $\operatorname{Er}(T)$ in this paper. The output from the $\operatorname{Er}(T)$ processor was routed to the data logger computer through an $\mathrm{A} / \mathrm{D}$ converter.

\section{Results and Discussion}

3.1 Agglomeration in a semi-continuous system

Three consecutive runs for each level of bridging liquid

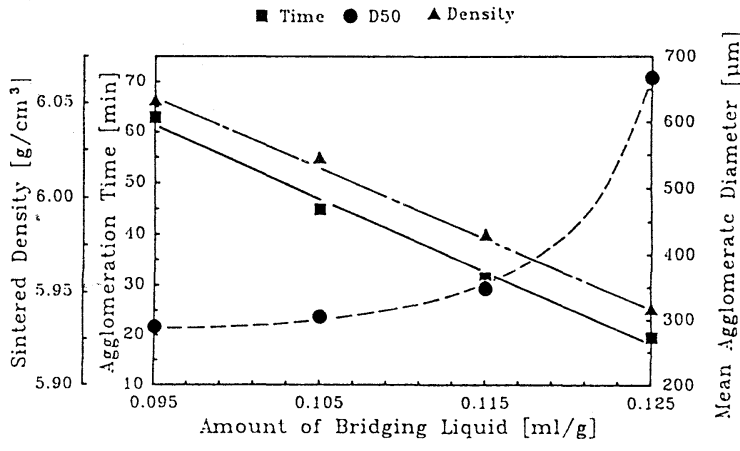

Fig. 2 Effects of bridging liquid dosage on three run averages of agglomeration time, mean agglomerate diameter $\left(D_{50}\right)$ and sintered density.

addition were carried out and the results are summarized in Tables 1 and 2. The effects of the amount of bridging liquid added on agglomeration time, recovery and sintered agglomerate properties can be recognized from these results. The effects of bridging liquid on the average of three runs of agglomeration time, mean diameter and density of sintered agglomerates are illustrated in Fig. 2. The agglomeration time is significantly prolonged when the bridging liquid added was reduced from 0.125 to $0.095 \mathrm{ml} / \mathrm{g}$. The $24 \%$ reduction in the amount of bridging liquid added caused a 3 folds increase in the agglomeration time. When the bridging liquid added was $0.125 \mathrm{ml} / \mathrm{g}$, the agglomeration time was $18.5,20.5$ and 19.5 $\min$ for runs 1,2 and 3 respectively. Deviation from the average time $(19.5 \mathrm{~min})$ is $\pm 1 \mathrm{~min}$. In the case of $0.095 \mathrm{ml} / \mathrm{g}$ bridging liquid addition, agglomeration time was $63.17,63.15$ and $62.55 \mathrm{~min}$ for runs 1, 2 and 3 respectively. Deviation from the mean is 0.54 min or simply $32 \mathrm{sec}$.

Recovery is noted to be decreasing with increasing bridging liquid addition. Although only a small increase in recovery is noted when the bridging liquid was reduced from 0.115 to $0.105 \mathrm{ml} / \mathrm{g}$, a more significant increase $(5.6 \%)$ is noted when the reduction was from 0.125 to $0.095 \mathrm{ml} / \mathrm{g}$. Ocular inspection revealed that inside the agglomerator, paste-like material lodged in the grooves increased with the amount of bridging liquid addition. Apparently this paste-like material which is difficult to remove during washing operation, accounts for the decrease in recovery.

The diameter of agglomerates increases with increasing amount of bridging liquid addition. The mean diameter of the
Table 1 Effects of bridging liquid dosage on agglomeration time and recovery.

\begin{tabular}{c|ccc|ccc}
\hline \multirow{2}{*}{$\begin{array}{c}\text { Amount of } \\
\text { Bridging } \\
\text { Liquid } \\
\text { (ml/g) }\end{array}$} & \multicolumn{3}{|c|}{$\begin{array}{c}\text { Agglomeration } \\
\text { Time (min) }\end{array}$} & \multicolumn{4}{c}{$\begin{array}{c}\text { Recovery } \\
(\%)\end{array}$} \\
\cline { 2 - 7 } & \multicolumn{3}{|c}{ Run No. } & \multicolumn{4}{c}{ Run No. } \\
\hline 0.095 & 62.9 & 63.2 & 62.2 & 97.8 & 98.6 & 96.9 \\
0.105 & 45.3 & 44.2 & {$[55.2]$} & 95.6 & 96.0 & {$[94.1]$} \\
0.115 & 30.3 & 33.3 & 30.5 & 94.7 & 96.2 & 96.3 \\
0.125 & 18.5 & 20.5 & 19.5 & 90.6 & 88.5 & 97.4 \\
\hline
\end{tabular}

Note: Enclosed in [ ] are the results when some of the bridging liquid spilled during addition. The spilled bridging liquid was approximated and added later. The results are rather different from those obtained when the bridging liquid added was accurately measured.
Table 2 Effects of bridging liquid dosage on properties of sintered agglomerate.

\begin{tabular}{|c|c|c|c|c|c|c|c|c|c|}
\hline \multirow{3}{*}{$\begin{array}{c}\text { Amount of } \\
\text { Bridging } \\
\text { Liquid } \\
(\mathrm{ml} / \mathrm{g})\end{array}$} & \multicolumn{3}{|c|}{$\begin{array}{l}\text { Mean Diameter } \\
\qquad(\mu \mathrm{m})\end{array}$} & \multicolumn{3}{|c|}{$\begin{array}{l}\text { Sphericity } \\
(-)\end{array}$} & \multicolumn{3}{|c|}{$\begin{array}{l}\text { Density } \\
\left(\mathrm{g} / \mathrm{cm}^{3}\right)\end{array}$} \\
\hline & \multicolumn{3}{|c|}{ Run No. } & \multicolumn{3}{|c|}{ Run No. } & \multicolumn{3}{|c|}{ Run No. } \\
\hline & 1 & 2 & 3 & 1 & 2 & 3 & 1 & 2 & 3 \\
\hline 0.095 & 293 & 294 & 282 & 1.13 & 1.14 & 1.13 & 6.050 & 6.046 & 6.050 \\
\hline 0.105 & 301 & 307 & [369] & 1.14 & 1.14 & {$[1.06]$} & 6.027 & 6.006 & [6.011] \\
\hline 0.115 & 339 & 349 & 355 & 1.06 & 1.06 & 1.07 & 5.974 & 5.989 & 5.980 \\
\hline 0.125 & 603 & 701 & 695 & 1.09 & 1.10 & 1.08 & 5.932 & 5.949 & 5.937 \\
\hline
\end{tabular}

Note: Enclosed in [ ] are the results when some of the bridging liquid spilled during addition. The spilled bridging liquid was approximated and added later. The results are rather different from those obtained when the briding liquid added was accurately measured. 


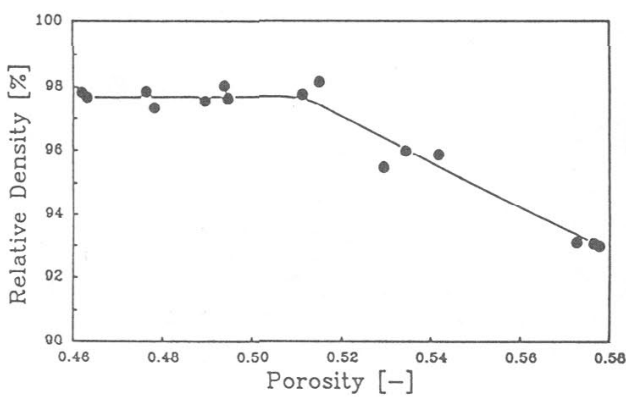

Fig. 3 Relationship between porosity of presintered compacts and relative density of sintered compacts.

sintered agglomerates were 290, 304, 348 and $666 \mu \mathrm{m}$ when the bridging liquid added were $0.095,0.105,0.115$ and 0.125 $\mathrm{ml} / \mathrm{g}$, respectively. The density of the sintered agglomerates decreases with increasing diameter. In the case of $290 \mu \mathrm{m}$ agglomerates the sintered density is $99.2 \%$ of the theoretical density. In another paper ${ }^{1)}$, the authors quantified the effect of porosity by using powder compacts as model agglomerates. The compacts were shaped as disks with diameter equal to $16 \mathrm{~mm}$. The porosity of each disk was varied by using different pressures during cold isostatic pressing (CIP). Fig. 3 shows the relationship between the porosity of presintered compact and the relative density of sintered compact. The
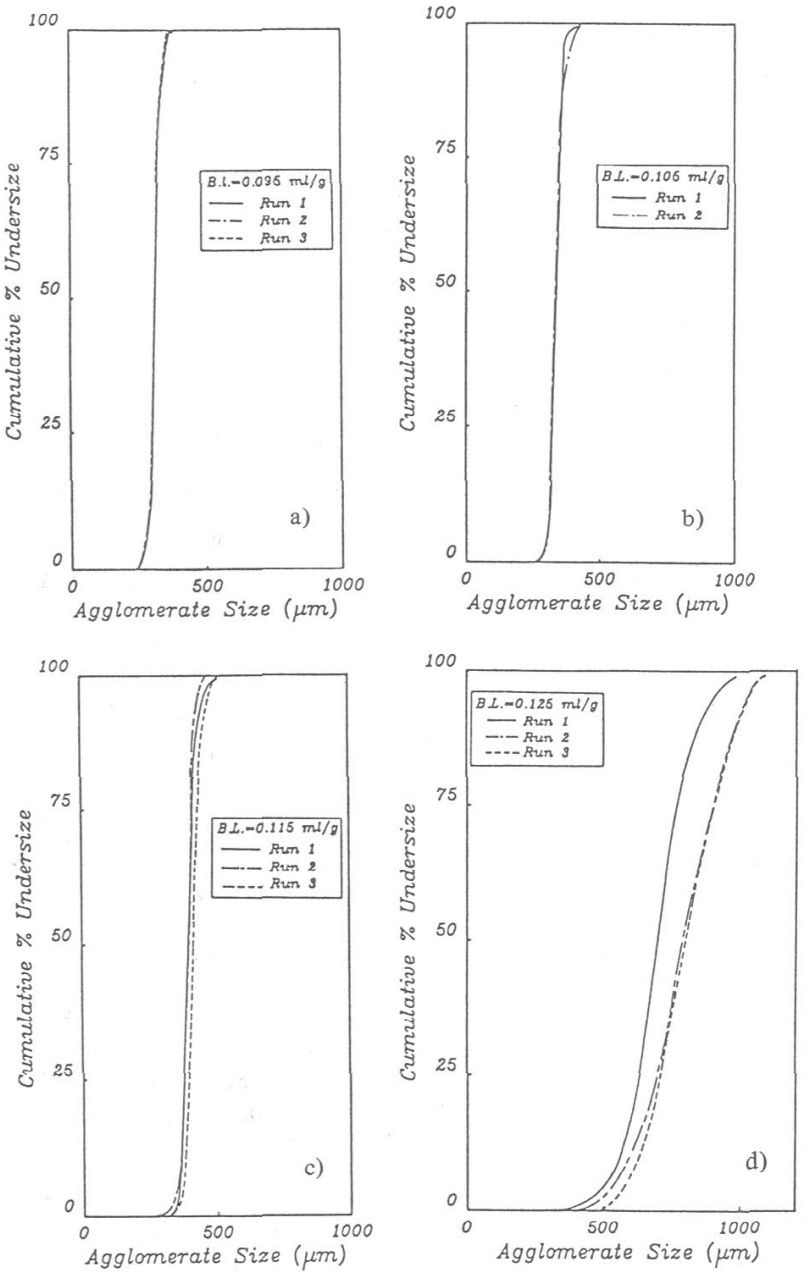

Fig. 4 Size distribution curve of the agglomerates for three runs of each bridging liquid addition. maximum relative density attained was in the neighborhood of 97.7\%. The high relative density of sintered agglomerates produced by the agglomeration in liquid indicates that the aggregates present in the starting powder are more effectively eliminated during wet state process of agglomeration in liquid than in the dry state cold isostatic pressing of powder compacts. The aggregates impede densification mechanism in the process of sintering ${ }^{8)}$. Another point is the effect of specimen size on density after sintering. The compacts are much bigger than the agglomerates produced by agglomeration in liquid. It can be expected that for the smaller agglomerates, pores at the core are relatively near to the surface and will be more susceptible to close during sintering.

In all cases, sphericity is within the acceptable range, i.e. less than 1.15. The size distribution curves from the three runs for each bridging liquid addition are shown inFig.4a) to d). In Fig. $4 \mathrm{a}$ and b, i.e. 0.095 and $0.105 \mathrm{ml} / \mathrm{g}$ bridging liquid additions, the sharpness and the overlapping of the distribution curves are noticeable. With increasing bridging liquid addition, $0.125 \mathrm{ml} / \mathrm{g}$, the size distribution curve exhibited some widening. This behavior can be attributed to the fact that with large dosage of bridging liquid, agglomerate growth proceeds rapidly and this rapid phase in agglomerate growth deviates in every experiment. In addition, the amount of paste-like material sticking to the vessel walls increases with an increase of bridging liquid. These sticky materials influence the amount of bridging liquid available for agglomerate formation, hence, affecting the growth rate and size distribution.

The minimal variance in agglomeration time and agglomerate properties and the close similarity of size distribution curves are indications of good reproducibility of the semicontinuous agglomerator. The above results demonstrate the technical capability of the system in producing highly spherical microagglomerates of 282 to $701 \mu \mathrm{m}$ diameter with nearly theoretical density. However, in order to repeatedly produce

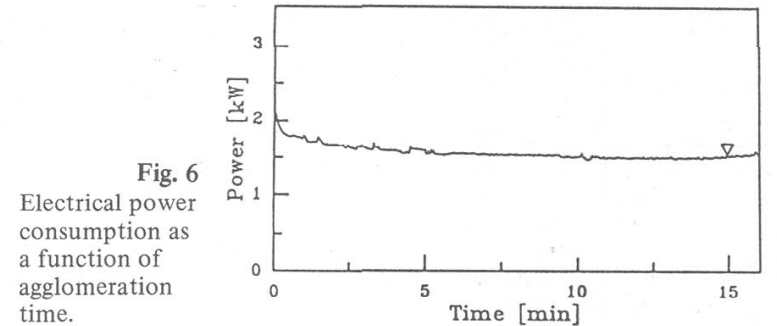




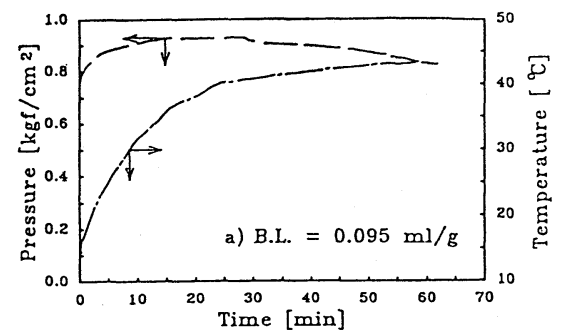

Fig. 10

Relative energy of noises emitted as a function of agglomeration time for different

bridging liquid dosages.
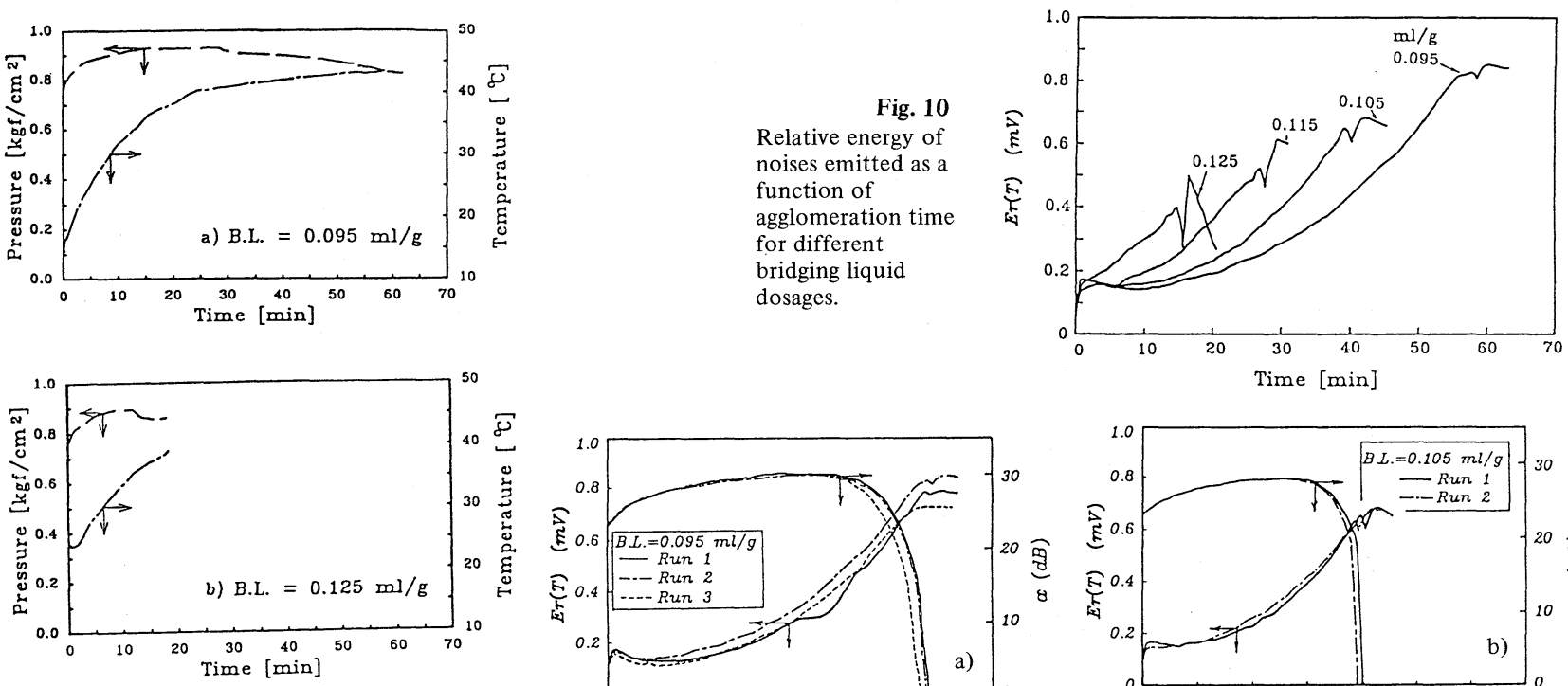

Fig. 7 Typical changes in temperature and pressure as a function of agglomeration time.
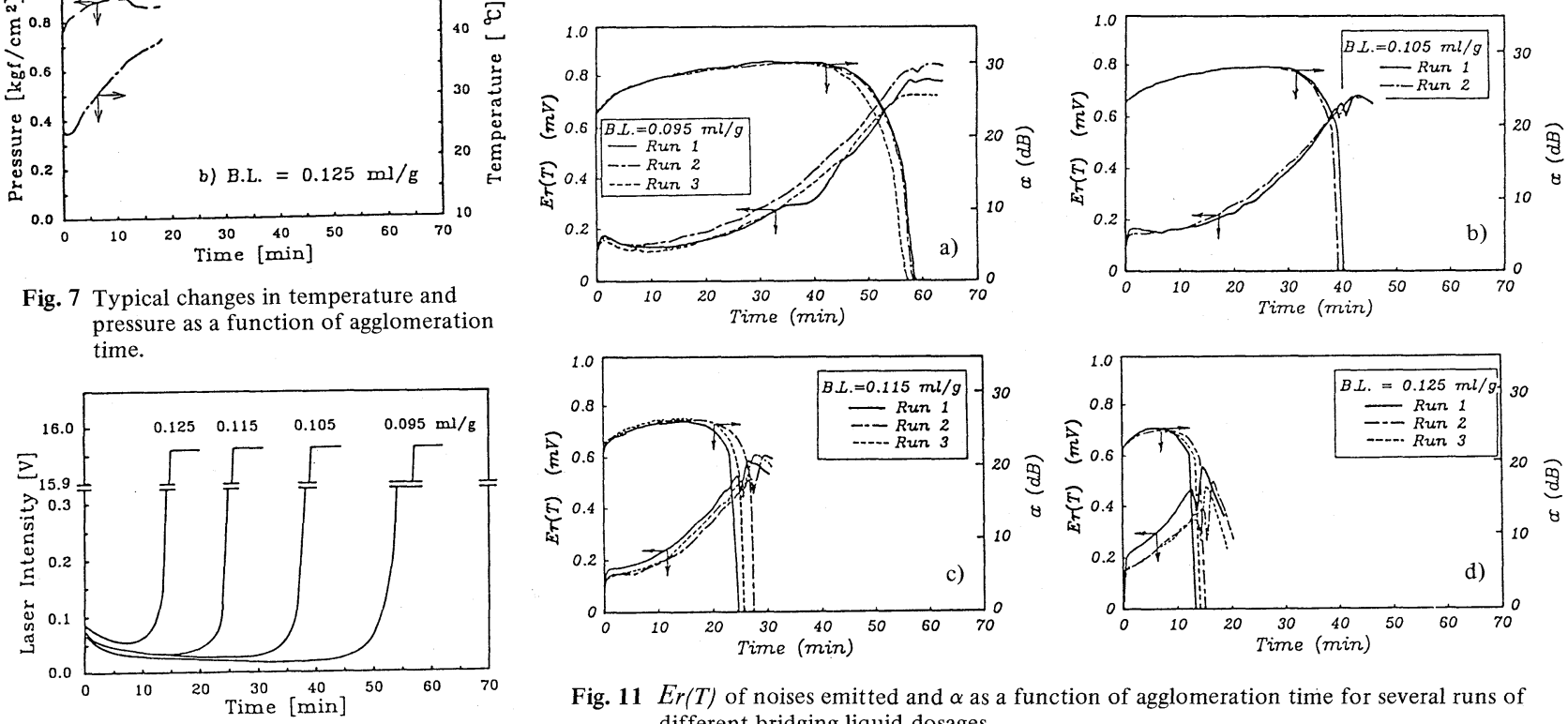

Fig. $11 \mathrm{Er}(T)$ of noises emitted and $\alpha$ as a function of agglomeration time for several runs of different bridging liquid dosages.

Fig. 8 Changes in the intensity of laser beam transmitted through the slurry as a function of agglomeration time.

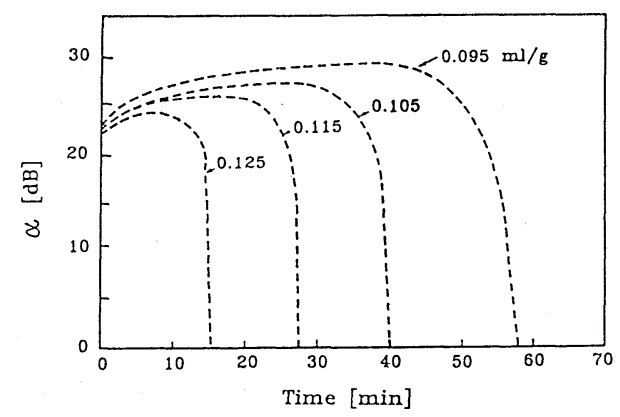

Fig. 9 Laser attenuation $\alpha$ as a function of agglomeration time. agglomerates with specified size it is essential to develop a good on-line system for monitoring agglomerate diameter. Some photo-micrographs of the sintered microspherical agglomerates produced by using the semi-continuous agglomerator are shown in Fig. $\mathbf{5}$.

\subsection{Monitoring Systems}

3.2.1 Power, temperature and pressure measurements A typical power measurement result during agglomeration with $0.125 \mathrm{ml} / \mathrm{g}$ bridging liquid addition at $1,840 \mathrm{rpm}$ is shown in Fig. 6. It can be seen that the power initially decreased, stabilized and did not exhibit any noticeable change even during the time when complete agglomeration was observed or the suspension became transparent, marked as $\nabla$ in Fig. 6.
Typical temperature and pressure curves are shown in Fig. 7. In Fig. 7a), the temperature initially increased and exhibited a plateau after $30 \mathrm{~min}$. In the case of high dosage of bridging liquid, the agglomeration time was too short for the temperature to level-off. The time-pressure curve also exhibited an initial increase, a plateau and then a gradual decrease. In $0.125 \mathrm{ml} / \mathrm{g}$ bridging liquid dosage, the decrease in pressure was more noticeable and almost simultaneous with the clearing of slurry. Generally, at the time when complete agglomeration is attained, pressure is noted to decrease but not enough to be noticed as can be seen in the case of low bridging liquid dosage. Moreover, correlating the agglomerate properties to the changes in the temperature and pressure of suspending liquid is rather difficult and will involve complicated thermodynamic relations.

3.2.2 Laser beam attenuation Typical changes in the intensity of the laser beam transmitted through the slurry with time for the four bridging liquid additions are shown in Fig. 8. In the initial stages the curves gradually decreased to minimum and then increased abruptly to maximum values. The rate of the increase is proportional to the amount of the bridging liquid added.

The decrease in the intensity of the laser incident beam $I_{0}$ can be expressed as ${ }^{9}$;

$$
\alpha=-10 \log \frac{I}{I_{0}}
$$


where $\alpha$ is the attenuation of laser beam, $I$ is the intensity of laser beam after attenuation caused by suspension and $I_{0}$ is the intensity of laser beam when only organic liquid is present.

The laser attenuation curves obtained by using Equation 1 for the data shown in Fig. 8 are illustrated in Fig. 9. It can be seen that the attenuation gradually increased, reached a peak and decreased to zero. The rate of increase and decrease of $\alpha$ depends on the amount of bridging liquid addition. It can be viewed as indicative of the kinetics of agglomerate growth. High value for $\alpha$ means that there is a big decrease in the intensity of transmitted beam due to high number concentration of suspended particles. When $\alpha$ decreases, the intensity of laser transmitted through the slurry increases, which indicates the reduction in the number concentration of suspended particles. The number of suspended particles decreased because the smaller particles agglomerated and formed larger particles. Thus when $\alpha$ is almost zero, the slurry is transparent and apparently complete agglomeration is attained.

3.2.3 Noise emission measurements The changes in $\operatorname{Er}(T)$ of the noises emitted during agglomeration in liquid for the four bridging liquid additions are shown in Fig. 10. The time$E r(T)$ curves are characterized by an initial abrupt increase, followed by a gradual increase, a rapid increase and a serrated end. The shape and peak height of the curves are dependent on the amount of bridging liquid added.

Mixed plots of the noise $\operatorname{Er}(T)$ and the laser beam attenuation as a function of time are shown in Fig. 11. The noise $E r(T)$ exhibited local minimum at the time when $\alpha$ dropped to zero. The depth of decrease at the local minimum of $\operatorname{Er}(T)$ increases with an increase in bridging liquid dosage. It can be noted that even with the same dosage of bridging liquid, the $E_{r}(T)$ curves exhibited some differences. After $\alpha$ declined to zero, the noise $\operatorname{Er}(T)$ curve continued to exhibit some changes. It would be of interest to correlate the last values of $\operatorname{Er}(T)$ to the agglomerate diameter. From Fig. 11, the last value of $E r(T)$ decreases with an increase in bridging liquid dosage. On the other hand, from the results summarized in Table 2, the agglomerate diameter increases with bridging liquid dosage. Thus, an increase in the final agglomerate diameter reduces the number of agglomerates and decreases the last value of $\operatorname{Er}(T)$. It can be considered that the changes in the $\operatorname{Er}(T)$ curves are manifestations of agglomerate diameter, number, etc. This postulate was confirmed and the changes in the agglomeration process were correlated to the features of noise emission and laser attenuation. This method was used in the development of an effective on-line monitoring system for the process of agglomeration in liquid and the results are reported elsewhere $^{10)}$.

\section{Conclusion}

The feasibility of producing highly spherical microagglomerates of zirconia of 282 to $701 \mu \mathrm{m}$ diameter and nearly theoretical density in a newly developed semi-continuous system was technically demonstrated. Decreasing the amount of bridging liquid addition results to the formation of agglomerates with smaller diameters and higher density after sintering. The minimal variance in agglomeration time and the similarity of the size distribution curves of agglomerates indicate the good reproducibility of the results obtained in the semi-continuous agglomerator. However, in order to repeatedly produce agglomerates with specified diameters it is important to develop an on-line monitoring system for agglomerate size. This is particularly essential for large diameter agglomerates.

The techniques of power, temperature, pressure, laser attenuation and noise emission measurements were tested for on-line monitoring of the process of agglomeration in organic liquid. The first three methods exhibited minimal variations that can be correlated to the process of agglomeration. On the contrary, the laser attenuation and noise emission measurements exhibited the changes that coincided with those of the agglomeration process. The "eye" or the laser attenuation method accurately marked the time when complete agglomeration was attained. The "ear" or the noise emission measurement method exhibited sensitivity to the changes in bridging liquid dosage, hence, to agglomerate diameter and number. Further understanding of the relation between the features of the noise relative energy and the agglomerate diameter or number can lead to the development of an on-line monitoring system for agglomeration in liquid.

\section{References}

1) Hirajima, T., Guinto, W., Tsunekawa, M. and Nakamura, M.: J. of Mining and Mater. Process. Inst., submitted

2) Sirriani, A., Capes, C. and Puddington, I.: Can. J. Chem. Eng. 47, $166-170,(1969)$

3) Mehrotra, V.P., Sastry, K.V.S. and Morey, B.W.: Int. J. of Mineral Processing, 11, $175-201,(1983)$

4) Nakamura, M.: Funtai to Kogyo, 23, 37 - 46, (1991)

5) Zuiderweg, F. and Van Lookeren Campagne, N.: The Chemical Engineer, No. 220, $223-227$, (1968)

6) Watano, S., Terashita, K. and Miyanami, K.: Proc. of 2nd World Cong. of Particle Technol., Vol. 3, 477 - 484, (1990)

7) Holm, P., Schaefer, T. and Kristensen, H.: Powder Technol., 43, $213-223,(1985)$

8) Rhodes, W.: J. of Am. Ceram. Soc., 64, $19-22,(1981)$

9) Yoshida, Y., Tsunekawa, M., Nishitsuji, A. and Kinoshita, S.: J. of Soc. of Powder Technol. Japan, 25, 621 - 626, (1988)

10) Hirajima, T., Guinto, W., Tsunekawa, M., Tadano, K., Nakajima, I. and Nakamura, M.: J. of Soc. of Powder Technol., Japan, 29, 428 $-433,(1992)$ 
半連続式液中造粒装置によるジルコニア微小球形体の製造

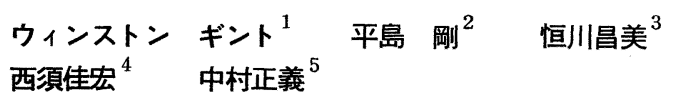

新しく開発された半連続式液中造粒装置を用い, ジルコニア微 小球形体製造試験を行った。試料として $2.6 \mathrm{~mole} \% \mathrm{Y}_{2} \mathrm{O}_{3}$ を含むジ ルコニア粉末 (比表面積 $6.76 \mathrm{~m}^{2} / \mathrm{g}$, 平均粒子径 $0.45 \mu \mathrm{m}$ )を, 茢濁 媒体としてパラフィン系有機液体を用い, 架橋液体添加量を 0.095 , $0.105,0.115,0.125 \mathrm{ml} / \mathrm{g}$ とし, それぞれの添加量で繰り返し造 粒試験を行った。架橋液体添加量の減少に伴い, 造粒時間は増加 し, 造粒体径は小さくなった。得られた造粒体を燒結した結果, 球形度 (粒子の最大長と幅の比) 1.14 以下, 密度 $5.93 \mathrm{~g} / \mathrm{cm}^{3}$ 以上 の極めて粒度分布幅の狭いジルコニア微小球形体を平均径 $282 \sim$ $701 \mu \mathrm{m}$ の範囲で得ることができた。繰り返し造粒試験を行った 際の造粒時間, 焼結造粒体の諸性状値の再現性は良好であった。 しかし, 造粒時間, 造粒産物の性状は, 架橋液体添加量のわずか
な変化に敏感に対応した。そのため, 電力, 温度, 圧力, レーザ 光隇衰量, ノイズの相対エネルギーを基にした造粒体成長過程の オンラインモニタリングの可能性について検討し，これがレーザ 光滅衰量とノイズの相対エネルギーを計測することにより可能で あることを示した。

$$
\begin{aligned}
& \text { 1. 学生会員 北海道大学大学院工学研究科資源開発工学 夏攻 } \\
& \text { 2. 正会員 工博 北海道大学助手 工学部資源開発工学科 } \\
& \text { 3. 正会員 工博 北海道大学助教授 工学部資源開発工学科 } \\
& \text { 4. 正会員 北海道大学大学院 (現資源環境技術総合研究所 } \\
& \text { 素材資源部) } \\
& \text { 5. 正会員 昭和シェル石油 (株) 開発部 } \\
& \text { キーワード: ジルコニア微小球形体, 液中造粒, 半連続式造粒装 } \\
& \text { 置, オンラインモニタリング }
\end{aligned}
$$

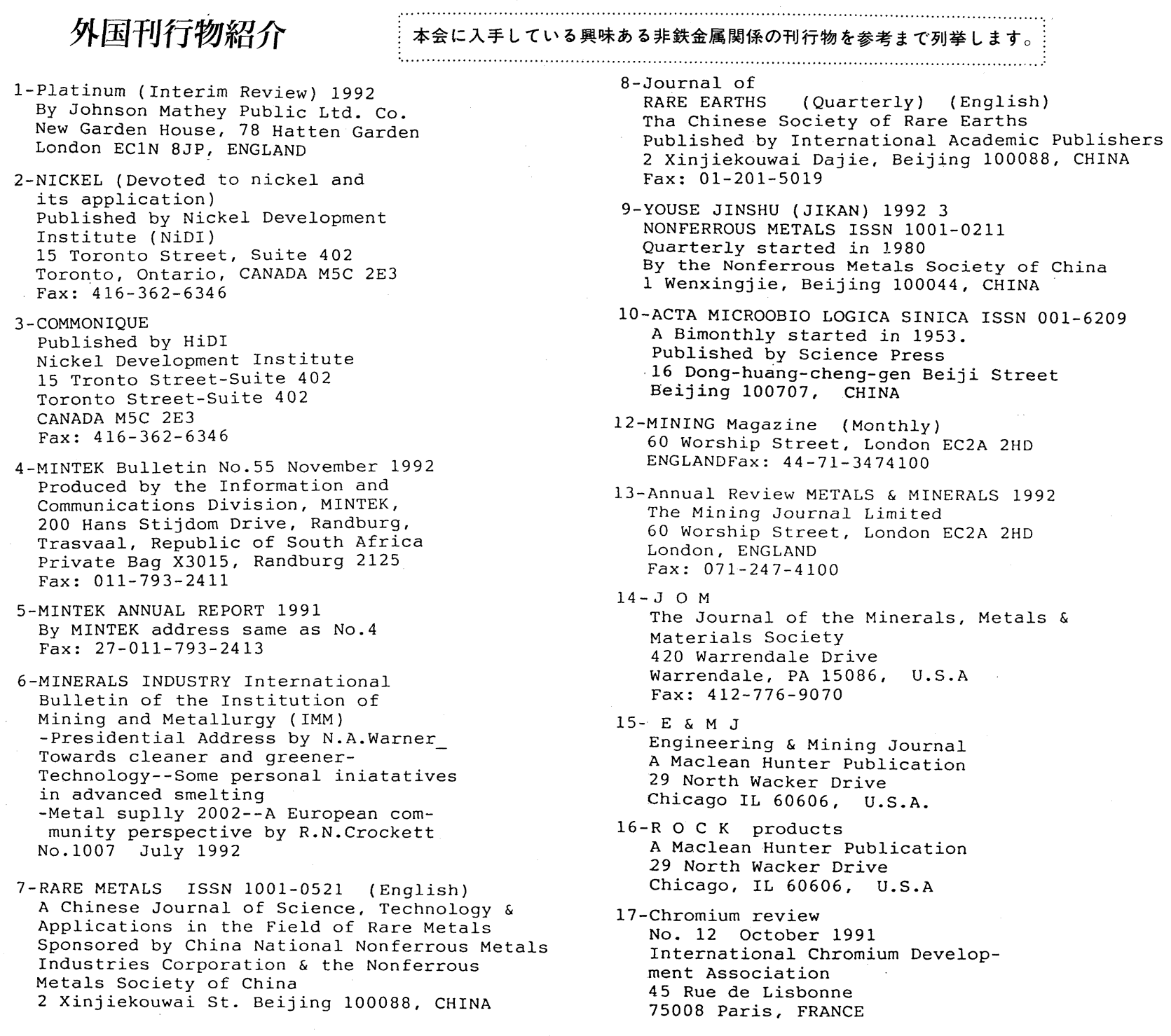

